\title{
Rational Thinking Based on the Connotation Construction of Higher Vocational Colleges under the Modern Vocational Education System
}

\author{
Liang Zhou \\ Xi'an Aeronautical Polytechnic Institute, Xi'an 710089, China.
}

1837638076@qq.com

Keywords: modern vocational education system, connotation construction, lifelong education.

\begin{abstract}
Strengthening connotation building is an important initiative and present the fundamental way to build a modern vocational education system lay a solid foundation of education in vocational education. In the process of constructing the modern vocational education system, the elements of the connotation construction of higher vocational education are gradually enriched, and the coordinated development of high vocational education, industry guidance, and the realization of the concept of lifelong education all provide rational choices for realizing the development of the connotation construction of higher vocational education.
\end{abstract}

\section{Introduction}

The Outline of the National Medium and Long-Term Education Reform and Development Plan (2010-2020) clearly states that by 2020, a modern vocational education system will be formed. Higher vocational education, as the top part of the emerging modern vocational education system, shoulders the backbone of career guidance. In the process of constructing China's modern vocational education system, higher vocational colleges are carrying out connotative development based on quality improvement. The higher vocational colleges in the new era have taken the road of connotative development and have become recognized as an effective way for vocational education. In 2011, the Ministry of Education of the People's Republic of China promulgated the three documents Faculty of Education [2011] No. 6, Faculty of Education [2011] No. 9 and [2011] No. 12, and the "Connotation Construction" has become a high-frequency vocabulary in higher vocational education. At present, the content of connotation building is increasingly abundant. The transformation of the development mode of higher vocational colleges, the guidance of the industry, and the establishment of the concept of lifelong education have further promoted the substantive development of higher vocational colleges.

\section{Accurately Grasp the Basic Connotation of Modern Vocational Education System}

2.1 "Long-Term Education Reform and Development Plan (2010-2020)" Issued in July 2010, the Same Time as the National "Twelfth Five-Year Plan" 96th Special Plan.

June 27, 2012, State Councilor Liu Dandong attended once again stressed that vocational education plays an important role in promoting China's transition of economic development mode when "the 2011 National Vocational Skills Competition" closing ceremony, should conscientiously implement education Planning outline. The instructions of the state leaders and the outlines of the education planning outline provide ideas and directions for the construction of China's modern vocational education system. It also provides a reference for interpreting the basic connotations of modern vocational education.

\subsection{Second, to Take the Road of Connotation Development Is the Fundamental Way for the} Development of Modern Higher Vocational Education.

Taking the road of connotation development, focusing on personnel training, scientifically positioning personnel training standards, optimizing the structure of personnel training, highlighting the characteristics of training, and improving the quality of education and teaching. Our institute attaches great importance to the quality of talent training in higher vocational education, and regards 
continuing to promote "connotative development" as a major task in improving teaching quality. Under the theoretical guidance and business guidance of the functional departments of education, our colleges and universities continuously improved the concept of running schools, strengthened the construction of connotations, and steadily improved the quality of teaching. The College adheres to the core concept of "work and study" and takes talent training as the foundation, closely combines regional economic advantages and industrial development and upgrading, constantly adjusts the professional layout, deepens the cooperation with the counterpart companies, and further integrates the idea of work-study into the process of personnel training. . With the advantages of aerospace, electronics and electrical appliances, deepen the cooperation between schools and enterprises, and continuously promote the innovation of the combination of work and study talents in higher vocational colleges; take the cultivation of top-notch innovative talents who dare to innovate, start businesses, and create; as a fundamental mission; improve the development of intensions Quality is at the core, closely integrating social needs in the process of integration into economic and social development, vigorously advancing quality engineering, deepening the reform of the personnel training model, improving the cultivation system of innovative high-professional talents, and accelerating the internationalization of talent cultivation; perfecting professional systems and curriculum reform As the main line, actively construct a professional construction system adapted to market development, develop new courses, and lay a solid foundation for professional development prospects. With teacher training as the key, teachers' vocational skills training will be strengthened to guide the dual development of teachers' scientific research and teaching; To support and standardize the hardware and software management of the training and practical training bases in and outside the school's management colleges, actively integrate with modern companies and markets, provide basic conditions for internships and training, and conduct in-depth research on higher occupations through the approach of " school-enterprise cooperation, work-study combination ". Education and Teaching Reform Grasp the core, grasp the key, focuses on major, national aviation industry development, regional social and economic development to make new contributions. In the No. 9 document promulgated by the Ministry of Education in 2011, it was also clearly expressed that strengthening the connotation construction and improving the quality of teaching has become the "lifeblood" for the healthy and sustainable development of higher vocational education, and it is the survival and survival of higher vocational colleges. The soft-core conditions for development and the construction of a modern vocational education system depend on the specific implementation of the connotation construction in vocational colleges, and the integration of school-enterprise cooperation and work-study integration can guarantee the full practical significance of the modern vocational education system.

\section{Rational Thinking on The Connotation Construction of Higher Vocational Education}

\subsection{Grasp the Core and Basic Elements of The Connotation Construction of Higher Vocational Education.}

Connotation construction of vocational education covers a lot of elements to form a close correlation between the various elements of a professional building as a link to influence the development of teaching resources, curriculum enrichment, to promote students' professional skills through teaching ability of teachers to mention liter the development, in order to achieve the quality of teaching can monitor sex; internship training base outside the school through the development and scientific management, standardize the behavior of students in professional practice, is almost enclosed system, professional and construction management. We must take professional construction as the core and do characteristic specialties. We must develop curriculum-based curriculum to develop school-based curriculum. We must train teachers, masters, teachers, and technicians to enhance the internal development of the college; and innovate in the talent cultivation model. To break through, deepen the cooperation between schools and enterprises; take the construction of training bases as the camp, and integrate chemical engineering within. 


\subsection{To Define the Positioning of Higher Vocational Education and Explore Multi-Channel Development Methods.}

The positioning of higher vocational colleges has a direct bearing on the direction of the development of the college. It will not only affect the organizational development pattern but will also affect the determination of organizational development goals. In terms of the orientation of the organization of the organization, higher vocational colleges must be clear about their own development space and interval positioning and distinguish the essential difference between higher vocational education and ordinary higher vocational education, and its essence is the positioning of the type of personnel training. Vocational education as a type of higher education in the country of the relevant documents have been obtained recognition. After experiencing the expansion and expansion of higher vocational education, with the transformation of socio-economic structure and development methods, higher vocational education is advancing toward the direction of improving connotative construction and improving the quality of personnel training, while actively exploring multiple channels. The transformation of the development model.

\subsection{Understand the Core Content of Promoting the Coordinated Development of Secondary Vocational Schools.}

In the "Guidance on Promoting the Coordinated Development of Secondary and Higher Vocational Education” issued by the Ministry of Education, Faculty of Education [2011] No. 9 clearly stated that the core task of the document is to optimize the structure, strengthen the features, and improve the level. Secondary vocational education and higher vocational education each bear different tasks. Higher vocational education must strive to explore innovative mechanisms and systems and establish the characteristics of higher vocational education on the basis of improving the quality of education and teaching; secondary vocational education should ensure the scale of education. Strengthen the construction of internal forces and improve the quality of personnel training. However, the difficulty in the connection between secondary and higher vocational education is the convergence of the curriculum. Therefore, to achieve the coordination of the curriculum plans for middle and higher vocational education, it is necessary for the secondary and higher vocational colleges to jointly develop a curriculum system and a talent training program, and reasonably design the vocational qualification certificate.

\section{Acknowledgments}

This paper is supported by the research project of education reform of the Shaanxi society of technical and vocational education. Subject number: SZJG-1623.

\section{References}

[1]. July Zhao Deepen teaching reform and improve the quality of teaching practice and exploration. Chinese Vocational and Technical Education. (2008) NO17.

[2]. Juli zhao,Fengshe. Tina. On the exploration and innovation of talent training mode in higher vocational education. Teacher Education Research, (2009) NO1.

[3]. Shouguang yak. The Connotation Construction of Model Vocational Colleges - Supporting Ideas and Constructing Practices. Beijing: Higher Education Press.2009.

[4]. Wei fan, Shukla ma. On speeding up the construction of demonstration vocational colleges. Educational Development Research. (2006) NO10.

[5]. Shouguang yak. On the key to strengthen the connotation construction of higher vocational education during the "Eleventh Five-Year " period. China Higher Education Research, (2007).NO7. 